Etnográfica

Revista do Centro em Rede de Investigação em

Antropologia

vol. $13(1) \mid 2009$

Vol. $13(1)$

\title{
Sai fora: youth, disconnectedness and aspiration to mobility in the Bijagó Islands (Guinea-Bissau)
}

Sai fora: jovens, desconexão e aspiração à mobilidade no arquipélago dos Bijagós (Guiné-Bissau)

\section{Lorenzo Bordonaro}

\section{(2) OpenEdition}

Journals

Electronic version

URL: https://journals.openedition.org/etnografica/1253

DOI: 10.4000/etnografica. 1253

ISSN: 2182-2891

\section{Publisher}

Centro em Rede de Investigação em Antropologia

\section{Printed version}

Date of publication: 2 May 2009

Number of pages: 125-144

ISSN: 0873-6561

Electronic reference

Lorenzo Bordonaro, "Sai fora: youth, disconnectedness and aspiration to mobility in the Bijagó Islands (Guinea-Bissau)", Etnográfica [Online], vol. 13 (1) | 2009, Online since 16 May 2012, connection on 11 February 2022. URL: http://journals.openedition.org/etnografica/1253 ; DOI: https://doi.org/10.4000/ etnografica. 1253

\section{(c) (i) (8)}

Etnográfica is licensed under a Creative Commons Attribution-NonCommercial 4.0 International License. 


\section{Sai fora: youth, disconnectedness and aspiration to mobility in the Bijagó Islands (Guinea-Bissau) ${ }^{1}$}

\section{Lorenzo Bordonaro}

In this article I portray the marginality, exclusion and social immobility of young people living in the small port of Bubaque in the Bijagó Islands. Reluctant to be involved in the village economy, but excluded from the port's market economy, aware of the weakness of the national economy, migration to Europe appears to them to be the only viable means of social promotion. Income and education are not the sole motivations of their aspirations to mobility, however. The young men's fantasies of migration to Europe are based on a developmentalist narrative framework that creates a cartography of centres and peripheries. Physical mobility towards the north is therefore also envisaged as a chance to obtain - or at least to claim - citizenship in 'modernity'.

KEYWORDS: youth, Guinea-Bissau, Bijagó Islands, involuntary immobility, migration, marginality.

I AM SITTING ON THE PORCH OF MY HOTEL IN THE LIGHTS OF THE generator, writing my field notes, when somebody calls me from the dark street (the Praça of Bubaque, the main urban area in the Bijagó Islands, with no working street lights, sinks into darkness at sunset). It is Delito, one of the young boys I am working with. He is a seventeen-year-old $9^{\text {th }}$ grader at the

1 This article is based on fieldwork carried out in 1999/2000 and 2002 in Bubaque. Funding was provided by the Fundação para a Ciência e a Tecnologia of the Portuguese Ministério da Ciência, Tecnologia e Ensino Superior. I am particularly grateful to the young men in Bubaque who wanted to share their dreams and their pain with me. Among many others, I would like to thank Agostinho, Beto, Domingo Carlos da Silva, and Xarifo. A special thank goes to Delito Mario Gomes. I am indebted to Miguel Vale de Almeida, Eric Gable, Henrik Vigh, Ramon Sarró, and Robert Rowland for their suggestions and encouragement during the whole research. I would also like to thank two anonymous reviewers of Etnográfica for commenting on this manuscript. 
local liceu (secondary school). His mother is from the island of Uracane, his father from Uno. He was born in Uno, but his family moved to the Praça when he was five. He lives with his father, who is a mason, while his mother is seldom at home, as she trades fish between Uracane and Bissau. He has a bad reputation among the 'whites'. Dora, the Portuguese hotel owner, has warned me: 'Look out with this one, Lorenzo. He is terrible! He has been charged with theft several times, but he always escapes arrest, as he is a minor.' He is my best friend on the island, one of the boys I spend most time with. He dreams of becoming a singer, and he is a songwriter himself, writing romantic songs for his girlfriend who lives in Bissau. He is shy and boastful at the same time, vain and naïve, with a whispering, hesitant voice.

He does not come into the hotel, as Dora has already rudely chased him off several times. 'Come on - he invites me - let's go and eat the world'. It was Saturday night, and 'eat the world' is the expression young people use to mean 'have fun'. I leave my notebook in my room and go out. I follow Delito along the dark streets full of bumps towards the harbour, with electric lights powered by generators, the centre of nightlife in Bubaque. The streets around the harbour are full of life on Saturday evenings. Boys and girls walk to meet their friends on the pier. All the shops and bars are open and crowded. Some boys sit and drink on the porch of the Dalillan bar, just in front of the pier. A small group come out staggering drunk, while, by the light of a powerful beacon, a few women are loading a boat with fish to be transported to Bissau. Those who have money to spend are waiting outside the small cinema. Tonight Schwarzenegger's Last Action Hero is showing. A pink curtain covers the entrance to the disco (250 CFA) that opens only later, but some boys and girls are already gathering nearby.

Delito and I stroll along the alley leading to the harbour, and we sit at Julio's bar. We start to talk about Europe, as we frequently do. Delito tells me about his dream of going to Europe to be a soccer player or a singer. 'All sons of Guiné,' he tells me, 'cry to go to Europe. Guiné is good if you have money. If God helps me, I want to get away from here.' He laughs, embarrassed, and imagines he is sitting on a plane taking him to Europe: 'When I sit on that plane, as soon as I sit down in my seat, I will cry with joy.'

In this article I will portray the marginality, exclusion and social immobility of young people living in the small port of Bubaque in the Bijagó Islands. Reluctant to be involved in the village economy, but excluded from the port's market economy, with no jobs, aware of the weakness of the national economy and with little if any hope for their future, migration to Europe appears to them to be the only viable means of social promotion. Income and education are not the sole motivations of their aspirations to mobility, however. The young men's fantasies of migration to Europe are based on a developmentalist narrative framework that creates a cartography of centres and peripheries, 
picturing Guinea-Bissau as a desperate and poor country, a nation of wretched people, while celebrating Europe as the land of development and opportunities. Physical mobility towards the north is therefore also envisaged as a chance to obtain - or at least to claim - citizenship in 'modernity'.

\section{BUBAQUE'S PRAÇA}

Situated at the estuary of the river Geba, about twenty kilometres from Bissau, the capital city of Guinea-Bissau, the Bijagó Archipelago includes about fifty islands, although only eighteen are permanently inhabited. ${ }^{3}$ The island of Bubaque, where I carried out my research, was the seat of the colonial administration and preserved its regional centrality after independence. On the northern coast of the island is the only urban centre of the archipelago, initially built at the beginning of the $20^{\text {th }}$ century by the Portuguese, simply called the Praça. ${ }^{4}$ Until the independence of Guinea-Bissau (1974), the Praça was just a few colonial buildings and a palm oil factory, though in the following years it grew rapidly northwards along the coast. Today, with an estimated population of $2,000,{ }^{5}$ the Praça is the seat of the regional government and the main port in the archipelago. Except for Bolama, Bubaque is the only island with regular transports to Bissau, though by small and often unsafe boats and canoes. The hospital, Catholic, Anglican and Adventist missions, the court, a few hotels and a market, all these elements give to the Praça the aspect of a small town, attracting traders, students and fortune seekers from other islands of the archipelago and from the rest of Guinea-Bissau. An 18-kilometre road constructed by the Portuguese colonial administration connects the Praça to the other end of the island and is the main link between the urban centre and the villages. Every morning, hundreds of people walk some kilometres from their villages to the Praça, to attend school or sell and buy food, wine or fish at the market.

2 The age range of the young men I worked with was between 16 and 22. 'Youth', however, had only partially to do with the actual biological age, being mostly a social condition defined by several overlapping characteristics (education, lifestyle, fashion, gender relationship, unemployment...).

3 Administratively, the archipelago constitutes the Bolama-Bijagós region, which is subdivided into four sectors (Bolama, Bubaque, Caravela and Uno).

4 In Guinea-Bissau, the term praça nowadays means 'urban centre'. In Portuguese, this word has several meanings: square, marketplace, but also garrison, fortress and stronghold. It is probably with this latter meaning that the Portuguese called their first garrisons along the coasts of Africa praças, and since it is mainly around these outposts that the urban centres grew along the centuries, the term has in Guinea-Bissau the meaning of 'town'. In the Bijagó Islands, the term is locally used to identify the urban centre of Bubaque as opposed to the villages (tabanka). The complete denomination should be therefore Praça de Bubaque, but this name is only used when one is outside the archipelago.

5 This figure was provided in 2002 by the local administration at my request. According to a study commissioned by the INEP on the archipelago (INEP 1990), in 1990 Bubaque had a population of 2936, 1662 living in the villages, and 1274 in the Praça. 
The urban structure of the Praça developed around the island's two ports: the one built in colonial times and now in ruins, and the other, presently in use, where boats to and from Bissau and the other islands dock and leave. Every day, near the new port, a small market is set up where people sell vegetables, palm nuts, fruit and fish. Behind the market are the ruins of the old palm oil factory: bent plates, huge boilers, monstrous gears still attest to what was once the main industrial activity of the archipelago. The factory, built by German entrepreneurs in 1913, passed to Portuguese control during World War II and was gradually abandoned after independence. From the harbour, a wide road climbs to the inner urban area. Along this street several Guinea-Bissauan, Senegalese, and Mauritanian traders have built their shops. Many tiny huts offer almost every kind of food (from canned tuna to candies), knives, machetes, dresses, bags, hats, gym shoes and music cassettes. A small cinema, two discos and several bars make this zone the heart of nightlife at weekends.

The Praça is what Mary Louise Pratt would call a 'contact zone' (Pratt 1992), where Europeans, Bijagó, and people coming from other regions of Guinea-Bissau or from neighbouring African countries to trade, cohabit side by side. Even though, according to the statistics, the Bijagó were still the majority in 2002, mainly after the civil war of 1998/1999 many Fulas, Balantas, Pepels and Mandingoes moved to the Praça. In 2002 about a hundred Senegalese, mostly Wolof and Nhominca fishermen, lived on the island of Rubane, just opposite Bubaque. Peul, coming from the Gabu region of Guinea-Bissau and from Guiné Conakry, managed most of the shops. A small group of Mauritanians owned four shops and a pharmacy. The European presence is evident as well. In recent years, French and Portuguese investors have built small hotels (in 2001 there were six hotels managed by Europeans) for the few tourists that come to the islands looking for natural beauty and deep-sea fishing. Other Europeans work for NGOs, in the administration of the national park of Orango, and in the Catholic mission.

However, the Praça can easily be portrayed as a marginal, peripheral place within the context of Guinea-Bissau. During my last stays in Bubaque, sporadic and unsafe means of transportation towards Bissau and rarely working telephone lines frequently have left the Praça totally isolated from the mainland, especially during the rainy season (from November to May) when sea conditions are bad. Despite its urban aspect and buzzing activity, the Praça - and the archipelago - are largely disconnected from the rest of the country and from the capital city Bissau. It is a place where you can feel really cut off from the rest of the world. This situation of decline must however be understood within the broader frame of the recent national Guinea-Bissauan economic and social trends. It is important to point out here that my fieldwork (in 2000/2001 and 2002), took place after the 1998/1999 civil war, in a critical phase in the history of Guinea-Bissau. 


\section{GUINEA WILL NOT RISE ANYMORE}

After independence in 1974 and for about a decade afterwards 'progress' (progresso) and 'development' (desenvolvimento) seemed at hand in Guinea-Bissau during the euphoria which followed the struggle for political liberation. Structural adjustments and political instability, however, have determined since the mid-80s a dual move in urban Guinea-Bissau, quite common in neo-liberal regimes. On the one hand, the country has opened itself to commodities, ideologies and media, while simultaneously unemployment and general economic weakness have started to emerge. The increasing availability of signs and goods has been accompanied by a general difficulty or impossibility in having real access to them for most of the population. The breach between the actual and the possible has been widening.

My fieldwork in particular, as I have pointed out, took place in the years following the 1998/1999 civil war, which impoverished the country and its inhabitants, almost completely destroying existing infrastructures. The 1998/9 conflict was propagandised to the people in Guinea-Bissau as a sort of liberation struggle from Nino Vieira's oppressive, authoritarian regime, as a step towards democracy and, hopefully, towards a glorious, fruitful period of freedom, development and change. The war obviously brought about destruction and death, but after, the transition to the new government was followed with great expectations and hope. 'Guiné i na lanta', Guinea will rise, people used to say. The elections held in November 1999 and January 2000 gave the PRS (Partido da Renovação Social) the relative majority in Parliament, while Koumba Yalá, head of the PRS, was elected president of the Republic in a climate of hope and enthusiasm that ended abruptly in a few months as people realised the government's incapacity to cope with the crisis in the country. Disappointment followed immediately, bringing about a feeling of disillusion and a sensation of unstoppable decay (Vigh 2006: 185). The following years seemed to confirm these pessimistic feelings.

In 2002, the army, led by Verrisimo Correia Seabra, intervened. Ialá resigned, the government was dissolved and a Committee for the Restoration of Democracy and Constitutional Order was established. Later that year the non-partisan Henrique Pereira Rosa was sworn in as president and António Artur Sanhá of the PRS became prime-minister. After the 2004 parliamentary elections, won by the PAIGC, Carlos Gomes Júnior became prime-minister. Presidential elections, hold in 2005, paradoxically brought Nino Vieira once more to the office of president of the Republic of Guinea-Bissau. In November 2008 a group of soldiers attacked the residence of the president Nino Vieira. Vieira was not hurt, and the renegade forces were eventually pushed back by the security forces. On the $2^{\text {nd }}$ of March 2009, chief of army General Batista Tagme Na Waie died after a blast that destroyed part of the military 
headquarters. In the following hours João Bernardo Vieira was assassinated by a group of 'renegade soldiers', as it was officially declared, in what was considered a revenge attack.

Actually, during the years of my fieldwork the state of Guinea-Bissau has been little more than 'sociological fiction' (Silva 1997: 73-74). The perception of decay was probably even more acute as it followed a period of optimism. People no longer expected the situation in Guinea-Bissau to improve in the future. It was not, in other words, a simple political crisis. It was something deeper. As James F. Ferguson wrote of Zambia, it was a crisis of meaning for people themselves (1999: 14).

Much of the perception the young men have of their country and their future must be understood within this wider national experience of 'decline'. In fact, the war and the persistent political instability of the country have heavily affected its economic performance, including the flow of aid. Widespread poverty in the urban classes is not only a factor of social instability, but is also generating scepticism about the new democracy and its capacity to cope with the future.

Young people throughout the country have been the most vulnerable to this national declining trend. Especially in urban areas, young Guinea-Bissauans share the dire conditions of youth that have been underlined in several African contexts. ${ }^{6}$ The issue is that of the problematic insertion of large numbers of young people into the post-independence socio-economic and political (dis)order. While opportunities for young secondary school graduates to pursue higher studies decrease, the number of unemployed young people increases at an alarming rate as the state - the principal employer of the diplomées - has been cutting down on its expenditure. Even educated young people are today confronted with a lack of opportunities, blocked social mobility, and despair about the future. In urban areas throughout the country young people seem constrained to remain young (dependent, deficient, single, etc.) with no easy access to wages, marriage, or autonomous residence, in a condition that Henrik Vigh powerfully defined as a social moratorium $(2006){ }^{7}$

6 There is a growing body of literature in anthropology concerned with youth in 'Third World' countries and in Africa in particular. See e.g. Mbembe (1985); O'Brien (1996); Anthropological Quarterly, 73 (3), July 2000, and 73 (4), October 2000; Politique Africaine, 80 (December 2000) and Autrepart, 18, edited by René Collignon and Mamadou Diouf (2001); the volume recently edited by Alcinda Honwana and Filip De Boeck (2005); Abbink and van Kessel (2005).

7 Though I won't specifically focus on this issue, it is important to underline that young people's perception of their own condition in Guinea-Bissau is not merely the outcome of this social and economic crisis, but is also produced by the appropriation and use of the idea of 'development' (whose origins can be traced back to the Eurocentric and colonial notion of civilization) and by the global spread of the development industry (Bordonaro 2007; forthcoming). 


\section{THERE ISN'T ANYTHING HERE}

Young people in the Praça of Bubaque clearly realize the condition they are stuck in, and share the national pessimism about the future of the country and the disenchanted attitude towards the new as well as the old governments. The boys of Bubaque accuse the politicians of being incompetent in leading the country, of making their own interests with public money while leaving the people to themselves. 'They come here by plane, parade in the streets by car only when there is an election. Then they disappear, they abandon us' - Agostinho told me one day. In the same vein, Xarifo told me:

You always hear 'I will be president to free the people'; 'I will be president to free the land of the Bijagó'. But when you get there you just eat money. You don't remember about the people you left behind. This is what the politicians do in Guiné. I think this is not a good thing. You have to do what you told the people, what you promised the people. It is just during the campaign that they come. They say in front of you all, if I am elected I will support you, I will put a water pump in the land of the Bijagó, I will do this, I will do that...' But so far, so far there is not even one water pump. 'I will give you electric light', they say, but there is not even one street lamp here in Bubaque.

Like many other young men in the Praça, Beto hopefully voted for Yalá in the 1999/2000 elections. He was however totally disappointed, and claimed that he was not going to vote for him in the next elections: 'He had four years to change things and he did not do anything!' He frequently remarked bitterly during our conversations that what truly prevented development in Guinea was the government: 'They all steal and nobody thinks about the development of Guiné’.

Most of the boys were competent political commentators, informed about the parties and their candidates, as well as about the latest political news. Facing the inability of Yalá to restore political stability, they were pessimistic about real political change and disappointed by the general, continuing inefficiency of the state, and by the rumours of corruption. 'Djitu ka ten', things won't change, everybody kept telling me, 'Guiné $i$ ka na lanta mas' (Guinea won't rise anymore).

To understand the condition of frustration and disillusionment in which young boys linger in the Praça of Bubaque we have to understand their 'expectations of modernity' as they migrated from the rural areas to an urban, if tiny, area. Though this cannot be generalized, several young boys I met had moved to the Praça from their villages, searching for their 'development' in an urban setting. As I have described elsewhere (Bordonaro 2007; forthcoming), their 
aspirations to 'development' led them to partially or totally reject the social hierarchies of the villages, moving to town to be enrolled in formal secondary education, to make some money in the market economy and to fulfil their dream of becoming 'modern'. Confronted with social exclusion and economic marginality, Bijagó youth in the Praça of Bubaque find themselves in a difficult in-between situation. As they wanted to abandon 'tradition', they realised that they were doomed to be excluded from the national urban economy.

It is in this specific setting that we have to understand the opinions of most young Bijagó men in the Praça. While refusing and looking down on village culture as 'non-developed', young men perceive that their country as a whole is lingering in a position of marginality by respect to the 'modern' centres that inspire their worldview. Despite their aspirations, most young men are confined in this wasteland - as Mark Liechty (1995: 187) defines it - between two worlds: the live local experience and the dream of modernity, in the incongruence between their expectations and their real life. With stunning lucidity, most of them share the idea that Guinea-Bissau is an unfortunate place without hope, excluded and cut off from the prevailing international discourse of global integration and with an insignificant position in the international chessboard.

This sense of isolation, of 'global disconnectedness', was bitterly expressed by the young men. One of the main complaints was emblematically the fact that the archipelago lacked a safe, rapid means of transportation linking it to the mainland. This obviously contributed to the feeling of isolation and was also, according to the young men, one of the main causes for the missed development of the islands. The sea, separating the islands from the mainland, has become a powerful symbol of the islands' disconnection from modernity, from a future of progress. Some boys refer to the 'misfortune of being born and of having to live in this sea'. Delito himself, complaining about the fate of being born in the archipelago, used the term castigo - punishment. ${ }^{8}$

For young men - always in a difficult economic condition - transport to Bissau can be expensive. The price of a one-way ticket to the capital city was 2500 CFA in 2002 ( $1 \mathrm{~kg}$ of rice costed between 270 and 300 CFA). The lack and expensiveness of means of transportation has also influenced the economic situation of the island, raising prices of imported goods and reducing

8 The lack of means of transportation is commonly held as another sign of the disinterest of the state for the people of the archipelago. At the same time, improvement of means of communication with the mainland is always one of the main points during electoral campaign speeches. These promises are always forgotten after the elections, but remembered by the people in Bubaque, who bitterly and ironically joke about the grandeur of the projects. Koumba Yalá, for example, promised the construction of a bridge linking Bubaque to the close island of Rubane during one of his speeches. To what purpose my interlocutors as myself could not figure out, but this gigantic undertaking always seemed to me as an amazing example of the grotesqueness of postcolonial power. 
the variety of products available. This situation is particularly uneasy for the young men, whose identity depends largely on the display of 'modern' commodities such as designer clothes and accessories (Bordonaro 2007).

This feeling of being disconnected from the rest of the world is even more acute as it is extremely difficult to get through to the 'outer world'. The telephone works sporadically and surface mail is not regular. A network of VHF radio created by NGOs and hotel owners links the islands to each other and the mainland, but obviously very few people can really have access to it. The only way to receive news from the mainland is by radio ${ }^{9}$ and $\mathrm{TV}^{10}$ (even if there are only a few TV sets on the island, where there is no electric power), but emblematically - these means allow one to receive messages and programs, but not to send one's voice beyond the sea. With few possibilities of getting away from the island physically, and even to establish a dialogue with the 'outer world', most young men feel absolutely cut off from a world they can grasp in fragments through radio and TV programs, commodities and tales of tourists and travellers, and in which they feel they can only participate as spectators.

The opening of wider horizons and the multiplication of imagined life possibilities bring about painful feelings of exclusion and frustration in the young people of Bubaque. Young men have the constant feeling that there isn't anything in Bubaque. I was really struck one day by this self-perception during a casual conversation while I was writing notes at a bar. A boy came by and asked me what I was writing. I answered that I was describing the environment in the Praça. He looked at me perplexed and stated, depressed, 'What do you mean? There isn't anything here. Absolutely nothing.' 'Well,' I replied, 'I am writing about young people like you... what are you, nothing?' 'Yes,' he said sadly, 'I am nothing.'

'There isn't anything here, there is no way, there are no chances...' - the complaint about their condition was often expressed in these negative terms during our conversations. 'What is good in Guiné? Nothing. There isn't anything. You just get enough, and if you have money you leave', Joaquim told me. Domingo commented:

People in Bubaque suffer. They don't have any good drinkable water. They don't have good transportation. Here in Bubaque we need electricity. We need a bus connecting the villages. We need a market, boats, water, a bus, electricity... we need almost everything.

9 These were the radio stations broadcasting in the archipelago: Rádio Djan Djan (only from 8 to 10 pm, regional, from Bubaque); Rádio Bombolon (national); Rádio Nacional da Guiné-Bissau (national - state-owned); RFI, Radio France Internationale (international - French); RDP África - Radiodifusão Portuguesa (international - Portuguese); Radio Sénégal Internationale (national - Senegal).

10 Only two TV channels are broadcast in Bubaque: TGB, Televisão da Guiné-Bissau, and RTP África (Portuguese). 
Young men seem to have a negative identity. What they do not have constitutes their actual world, defining their local specificity. Most conversations about the condition of young people in Guinea-Bissau focus on what they lack, what they need. This attitude of despair and victimization that most young men manifest cannot but recall Mbembe's comment that the 'cult of victimization' and the 'narratives of loss' are common features of African conceptions of African self and history (2002). In Bubaque, the cluster of sentiments triggered by this self-perception is forcefully expressed by the Kriol term koitadesa, denoting the perception of being wretched and hopeless, the surrender to the difficulties of life and adverse fate. As Wilson Trajano Filho (2002, 2004) pointed out, the term is crucial for self-perception in the Guinea-Bissau Creole world, just like other similar phrases such as 'djitu ka ten' (that could be translated as 'accept things as they are because there is no way to change them'), or 'n'sufri' (literally 'I suffer', but meaning rather 'I stand, I stand the suffering').

Mark Liechty (1995) pointed out that the modernist national ideology of development and progress creates a national identity based on external referents. Actually both these remarkable perceptions of disconnectedness and nothingness rest on the assessment of Bubaque and Guinea-Bissau by comparison with other places of reference, imaginative horizons, a somewhere else. Young men situate the archipelago and Guinea-Bissau at the beginning of the unilinear, teleological narrative of development and therefore at the edges of the world-system. The situation of Guinea-Bissau is evaluated vis-à-vis other nations of Africa or Europe. As Beto often commented sadly, 'Here in Bubaque, in Guinea, we have a delay of centuries by comparison with Europe.' The collapse of the state is in this sense the political evidence of the breakdown of the grand narrative of national progress and development, something young men have ceased believing in. Young men no longer hope in Guinea-Bissau.

This feeling of disenchantment brought about by the weakening of the initial élan of post-independence ideologies and the growing relevance of market economy and consumerist culture is powerfully caught in Flora Gomes' film Udju Azul di Yonta (Yonta's Blue Eyes, 1991) portraying the city of Bissau in the early 90s. In one scene a distraught Vicente - a disenchanted hero of the independence struggle who has only grudgingly adapted himself to postrevolutionary society - vilifies Yonta: 'You have replaced ideals with clothes and night clubs.' And she retorts: 'It's not my fault if your ideals are spoiled'. Experiencing on a personal level this general crisis and national decline, this feeling of spoiled ideals, it is not surprising that young men's individual search for status and development is always imagined outside the rhetoric of national progress, bringing most of them to envisage their self-realization only outside the country. 


\section{OUT OF HERE}

Arjun Appadurai insightfully remarked that for many societies, modernity is an elsewhere (1996: 9). Facing a globalisation that triggers self-perceptions of exclusion and marginality and disillusioned by the inefficiency of the postcolonial state, all the boys of the Praça regard migration to Europe as the only possible way out. As for the young men of Bissau portrayed by Henrik Vigh, migration is one - if not the easiest - 'navigational tactics' to escape from social exclusion and marginalization (Vigh 2006: 106). The fancied migratory paths lead towards Bissau, Dakar, Conakry, but everybody's dream is still Europe, a centre by contrast with a multitude of peripheries, an idealized spring of power and wealth. ${ }^{11}$

Among the main reasons for migration are obviously income opportunities. Reaching Europe is pictured as the only real chance to improve a young man's economic condition. The common idea about Europe is that 'there' (lá) it is extremely easy to find a job and to earn good money. Given the social and economic marginal position of the boys in the Praça, economic promotion expected through migration is the only chance to have access to marriage, to a house, to important changes. In other words, it is the sole option for becoming a socially acknowledged adult.

Often, education and income are intertwined in young boys' migration fantasies. Agostinho, for example, was fascinated by the possibility of a better education. His greatest desire was helping his country and his family. To do so, he claimed, he had to finish his liceu and enrol at university, maybe in medicine. Obviously fora, 'outside'.

The term fora (outside, out) was recurrent in my conversations with the young men, and emblematic of their perception of confinement. Sai fora (get out) was the Creole expression they constantly used when talking about their desire to migrate. This simple phrase, pronounced with glittering, dreamy eyes while snapping at the horizon, was a powerful expression of their feeling of confinement, of their complaint about their sealed-off, blocked life (vida empatada).

Carlos told me he wanted to get out to get higher education (pa bai furma), to be able to help his country and his family. Even though he considered going back to work in Guinea-Bissau after his education, he clearly realized that the working conditions in the country were despairing.

11 Gardner points to the existence of many centres or cores of capitalism, and of cultural cores other than the West (1995: 273). This might even be true (see also Van Binsbergen, Van Dijk and Gewald 2004: 18-19), but what I am describing are the features of local imagination in Bubaque, which actually keeps reproducing the binary distinction between 'the West and the rest'. 
Maybe I'll just come back for holidays. Being a doctor, a teacher, or any other thing in Guinea-Bissau is pure madness. There are no job opportunities here, and it is useless to be trained for a kind of job that does not even exist here, or that is underpaid. A high school professor earns 15,000 CFA a month!

However, Carlos complained bitterly, getting out was almost impossible for a young man like him. The only chance he had - he said - was a scholarship to study abroad. 'But these grants,' he exclaimed angrily, 'are always awarded to the sons and daughters of the politicians! Their children leave to study abroad and we, coitadis, have to stay here.'

Delito was probably among the most enthusiastic about 'getting out':

Here it is always the same. I am tired of Guinea-Bissau; I want to get out. You see, all sons of Guiné want to go to Europe [tudu fidju di Guiné misti bai Europa]. The only ones that do not want to go, it is because they have something here, but I don't have anything. Guiné is good if you have money [Guiné i sabi si bu tene dinhero].

One afternoon, a few days before my departure, I asked what he would do in Europe:

D: Well, my profession, what I have always wanted to be is either a musician, or a soccer player. I like Europe very much. Very much. When I go to Europe, I will study music, if God helps me. There are two reasons why I want to go to Europe: music and soccer.

L: What about Guiné? Don't you have any possibility here to do what you want?

D: No, here I don't have any chance. In a neighbouring country, maybe, but not here. I am tired of it. There is no way here. The only chance here is to get help, there is no other way but asking for help. The situation here in Guinea-Bissau is difficult. I want to move. We don't want to just sit here. I am tired of Guinea, Europe is a good land. I don't want to stay here, I want to move [N'cansa di Guiné, Europa i terra sabi. N'ka misti fica lì, N'misti passa].

Migration, however, is a luxury that only a few can afford in Bubaque. In most cases, young peoples' desire to escape is frustrated, and they remaine between the village and the dream of Europe, adopting survival strategies in the Praça or in Bissau. In some cases, even moving to Bissau can be a difficult step, as only a few of them have a relative in the capital city willing to support them during their studies, while finding a job has become increasingly difficult. The idea of involuntary immobility, proposed recently by Jørgen Carling (2001; 
2002) as a central issue in contemporary migration studies, seems perfect to describe the situation of youth in Bubaque.

Due to the dramatic lack of opportunities to 'sai fora', to leave, I have found in Bubaque a real mythology surrounding migration and those who have done it. Those who have succeeded in leaving the country have a semi-legendary status and are envied and respected. Domingo once described to me how grants from the Portuguese government were awarded, in a way that reminded me of the Polynesian cargo cults. His description went down to the tiniest details, like the procedures for handing in the paperwork, the precise deadlines, how faxes were sent from the Portuguese embassy, how your passport was stamped before leaving the country to allow you to get out. He was speaking with frantic, dreamy eyes about how your family took you to the airport, how you got there and checked your luggage in.

Besides the chance of winning a scholarship, unrealistic possibilities, sorts of urban legends, circulate among young men. Several boys told me of a 'friend of a friend' who met a white man, they got on together well, or, in one of the variants, he saw him playing soccer and he turned out to be a talent scout or a soccer trainer. So, out of the blue, a few hours before his departure, he told him 'let's go', and 'here you go, over the moon, you pack your bags, bid farewell to your family and you go'.

Literature on globalisation underlines that while planetary connections increase, the relationship between centres and peripheries becomes unstable and tends to be less clear-cut. This is not always necessarily true. In Bubaque, young men are aware of what is going on 'elsewhere', of how life could have been different. Nevertheless, this very perception, imaginary and ideological as it is, of a 'global, modern society' triggers frustration and exclusion, as young men feel like prisoners in a cage. While their expectations are frustrated every day, school, the media, and their own national government promote the mythical existence of a rich, dynamic centre, to which they have to aspire. Everybody is desperate to go away, everybody keeps talking about this. However, the real chances are so scarce that this desire is transformed into a cult of escape populated by bureaucrats, rich white men and soccer talent scouts.

Young men in Bubaque have a strong 'faith in the foreign' as Kathy Gardner (1995) wrote referring to Bangladesh. They are sure that life elsewhere is better and easier. The origins of this 'almost religious faith in a redemptive West' (Kelsky 1999: 232) are multiple. While income and education are indeed strong motivations, we cannot ignore broader cultural themes that can provide insight into how migration is locally conceived and imagined, reframing African migration further into cultural and historical cadres rather than as the mere outcome of a rational decision of economic agents.

Young men's desire for mobility in Bubaque is often tinted with a nuance of fascination for 'Europe'. This motive is not immediately manifested, as it is in 
contrast with their tactical self-representation as 'victims' - a form of limited agency Mats Utas (2005) defined as 'victimcy'. But indeed their burning desire for mobility responds to the ideas of seduction and fascination as much as, if not more than the rational calculation of the economic and social gain expected through migration. Acknowledging the seducing power of the idea of Europe is therefore an important step in understanding migratory imagination and motivations.

Young men's fantasies of migration to Europe are based on the same developmentalist narrative framework that, as I noted earlier, creates a cartography of centres and peripheries, picturing Guinea-Bissau as a desperate, poor country, a nation of coitadis, while celebrating Europe as the land of development and easy opportunities. ${ }^{12}$ The development industry and the media, for their part, contribute to the consolidation of this imaginary geography, triggering desires and fantasies towards phantoms, instilling the idea of progress and that progress can come only from the 'outside'. The moral status ascribed to the migrant in the local imagination is the fallout of this moral global geography, and is not immediately likened to economic promotion. Europe is for everybody terra sabi, a good and beautiful land, where dreams of education and wealth can come true. But moving to Europe is also providing for something much more valuable. Physical mobility towards the north is envisaged as a chance to obtain - or at least to claim - citizenship in modernity (a citizenship that paradoxically can only be displayed at home, because it is constantly denied in the host country; Bordonaro 2003): the new 'cosmopolitan' identity shown-off by returning migrants has a huge motivating power upon young men.

Aspiring migrants perceive geographical mobility as personal development: 'misti bai Europa pa bai furma, pa bai disenvolvi nha mentalidade', 'I want to go to Europe to receive an education, to develop my mentality', claimed Domingo, when asked about his reasons for wanting to migrate. Migration to Europe is conceived as a transforming experience that turns travellers into exceptional people, endowed with charismatic power. The upward movement in the world's moral geography is supposed to be reflected in migrants' subjectivity and character, in their 'mentality'. Those coming back from Europe, I was often told, 'e na torna fino', they come back refined, sophisticated and educated.

The notion of development, as the young men in Bubaque use it, refers not merely to the improvement of economic, social and health conditions, but also to a personal, psychological transformation. Apparently, one of the goals of

12 Similar conclusions have also been drawn in other contexts. In Cape Verde, for example, Lisa Åkesson underlines, the notion of home as barren and impoverished has traditionally been counterpoised to the image of stranjer as a 'paradise' where the ones who work hard can get everything they want. Home and stranjer are seen as fundamentally contrastive (Åkesson 2004: 21 ). Kathy Gardner observed that the dialectically contrasting images of homeland and the receiving countries are 'the ideological concomitant of international dependency' (1993: 1). 
young people moving to town, or willing to move on to Bissau or to Europe is to develop themselves, their 'mentality'. The idea of 'self-development' shows how socioeconomic indicators can infiltrate into the psychological domain, re-enacting locally bio-cultural colonial concerns about the different stages of evolution of races (Vigh 2006: 203-204). Underdevelopment shifts from a socio-economic condition towards a psychological, personal, mental state, the former being merely the outcome of the latter.

In Bubaque, when somebody adopts a way of life associated with urbanity and the institutions of a modern nation-state, like settling in town, having a paid job, attending school, wearing 'Western' clothes, people say that he 'has gone to become a white', 'bai sedu branku'. White, branku, are also several things associated with urbanity and therefore, indirectly, with the features of the Portuguese colonial presence - school (skola do branku), drugs (mezinho di branku), and even wealthy lifestyles (vida di branku). This metaphorical use of racial notions in Guinea-Bissau dates back to the 19th century, where the designation 'white' - meaning 'Portuguese' when the relationship was with strangers - was used to indicate all free individuals gathering around the praças, as well as everyone with noteworthy political or economic power, regardless of his/her real skin colour (Silveira 1998: 233).

Europe, 'terra branku', is the quintessence of whiteness in Bubaque. Those leaving for Europe, it is said, would likely come back branku, white. Migration to Europe is in this metaphorical sense considered as a process of whitening - as if the binomial black/developed were 'unthinkable', short-circuiting some colonial mainframe still to be post-ed (Vigh 2006: 204).

In a provocative manner, I would employ the colonial term 'civilization' to refer to the process of social and psychological ascension potential migrants are expecting to go through in their migratory path. The term was not directly referred to in my conversations with the boys. And it has a distinct colonial flavour. It is exactly for this latter reason that I think it could be used to highlight the colonial legacies biasing most dreams of migration, the moral meaning of migration itself, and the very relationship between African migrants and European host countries.

In the Portuguese colonial order, civilisation was a process of individual 'transformation' that was supposed to integrate Africans into Portuguese society, making them catholic, Portuguese in culture, and part of a wage-earning, market-oriented economy. The native policies in the colonies were based on the distinction between the civilizados and the indigenas, ${ }^{13}$ introduced in 1914

13 A comprehensive labour law was issued in 1899 and a land law in 1901, but the codification of all the decrees affecting the indigenas was not carried out until the early days of the Estado Novo, and was incorporated in the Estatuto Político Civil e Criminal dos Indígenas of 1929. The legislation was revised in 1954, when the term assimilado came to replace civilizado, but it was abolished only in the major reforms of 1961 . 
by the Lei Orgânica da Administração Civil. According to this legislation, an African could apply to the local administration for a certificate of civilizado, in order to enjoy theoretically all the rights and obligations of a white Portuguese (Oliveira Marques 2001: $25 \mathrm{ff}$.). The indígenas had to pass a 'civilisation' test that verified their ability to read, write and speak Portuguese 'correctly', their employment, their 'good behaviour' and their abandonment of 'tribal usages and customs'. The legal distinction between civilizado and indígena (despite minor changes in the legislation) continued up to 1961, when it was abolished and all Portuguese Africans were in theory accorded equal status with metropolitan Portuguese (Newitt 1981: 186).

The moral meaning of migration among the young in Bubaque seems to respond to the very principle of the 'civilization process'. If on the one hand young men seek wealth through migration, they also aspire to a process of moral and social transformation showing integration not necessarily in the receiving context but into the wider global cosmopolitan community. Migration is locally conceived as a process of both integration (globally) and distinction (locally) through self-transformation that only partially has to do with economic factors. Features of the colonial ideology are still re-enacted in present acts of imagination. The colonial distinction between civilizado and indigena is reproduced under the terms migrant/non-migrant, as far as integration in or at least relationship with the 'developed, civilized world' is concerned.

\section{CONCLUSION}

In a famous lapidary comment Achille Mbembe claimed that in Africa, globalisation seems to mean only 'licking at the shop-window'. For young people in Bubaque, as I have shown, the widening of their horizon only means a painful perception of being far and disconnected from the places where 'things happen', confined in a remote place where 'there isn't anything'. Young men marginalize their own lives in a discourse of modernization and desire. As Liechty underlined, 'the rhetoric of modernization, progress and development wafts into the image worlds of media to give people an acute sense of marginality' (1995: 188). There may indeed be ever increasing interconnections between different points on the globe, and an ever increasing density of flows of people, goods, and information, but this is far from being a uniform process. It is, in fundamental and structural ways, profoundly uneven. Despite the major narrative of 'globalisation', the economic world order creates marginality as much as connections (Ferguson 1999), a situation that shows stunning continuity (both political and discursive) with a world order that originated in the colonial era (Feldman-Bianco 2001: 477).

Dual categories like developed/underdeveloped, centre/periphery, which may be traceable to the period of colonial rule, continue to have relevance and 
are locally used because they express something fundamental about a world order that exhibits marked continuities with the asymmetries of the colonial era. ${ }^{14}$ They capture the complexities of contemporary experience and the social, cultural, political, and economic process that have shaped people's lives over the years of colonial and postcolonial history, retaining, as Philip Thomas wrote about Madagascar, "interpretive power as signs that capture something about continuities in people's political impotence and economic marginality' (Thomas 2002: 367, see also p. 373).

Recently, in a comprehensible effort to show a certain agency of people living in marginal and peripheral contexts, mainstream anthropological literature exploring the cultural effects of 'globalisation' has focused mainly on 'localizing strategies', highlighting how people in specific places appropriate external elements and transform them into aspects of their own world. This process is crucial - witnessing the resilience of local agencies - and cannot be overlooked. We need however to acknowledge another local process, prior and moving in the opposite direction. We might call it 'globalizing strategy', denoting the local aspirations to the 'global', how people crave for and dream of it, however they might locally configure it. In our fetishization of local agency, we cannot ignore people's efforts to be 'connected', to become 'modern' and 'cosmopolitan', which are spread throughout the world. This social phenomenon is increasingly relevant, shaping local cultural practices and imaginations in most regions of the world. The aspiration to citizenship in the 'modern' world is a distinctive feature of local realities - an aspiration to membership of the global order that is however often negated or postponed.

\section{EPILOGUE}

The night before my last departure from Bubaque in 2002, many young men came to my hotel to bid me farewell, asking for last-minute presents. Among them was Delito, wearing his perennial red Nike baseball hat. At first, he asked me for some help to put together a band. I answered in the usual way, that I was there on a scholarship to carry out research, and that I was not a rich man. He gave up, and told me he did not really mind. We were sitting on the porch of Dora's hotel, just in from the street. We remained silent for a while, and when I turned to him, I realized he was crying. In Praça, a man is a man, and a cool man must be even manlier than the others. And there he was, crying in front of everybody. I tried to console him, imagining what he might be mulling over: his frustration at remaining on the island while I was leaving. I felt uncomfortable, and I guessed he too might be ashamed, so I proposed a walk along the dark streets of Praça. As we walked side by side, 
Delito explained to me, sobbing, that that was the way he was, that he had got to like me and those tears were for the saudade he was feeling already. It was true, he continued, he had many friends, but he never had a stranger like me as a friend, somebody to talk to about his dreams, about Europe, about his future. 'For you', he accused me, 'it is just work. You come here, you ask about my dreams, but tomorrow you'll be gone, leaving me here, and you will forget about me'. What could I tell him? How could I reply to the heaviest accusation that can be levelled against anthropology, of exploiting human relationships, at times intense and troubling, for work, for a career, for personal benefit? I tried to explain to him that it was not always like that, that with him the relationship had been different, that I would not forget him. He remained silent for a while, and then he gave me his last present, one I cannot forget. He had composed a song for me, about our friendship. He had not finished it yet, but as I was leaving the next day, he wanted me to hear it before I left. To leave, to go, sai fora... I almost felt guilty at the chance I had to go away. I felt so sympathetic towards him, as I sensed his frustration, his exasperation. With his timid and hesitant voice, he whispered sobbing a song about friendship, saudade, about how little money had to do with our relationship. I held him tight. Then he bade farewell and left. The next morning he remained on the seashore until my canoe sailed out of view behind the island of Rubane, waving his red Nike hat now and then.

\section{REFERENCES}

ABBINK, Jon, and Ineke VAN KESSEL (eds.), 2005, Vanguard or Vandals: Youth Politics and Conflict in Africa. Leiden, Brill.

ÅKESSON, Lisa, 2004, Making a Life: Meanings of Migration in Cape Verde. Göteborg: University of Göteborg, PhD dissertation.

APPADURAI, Arjun, 1996,Modernity at Large: Cultural Dimensions of Globalization. Minneapolis, University of Minnesota Press.

BORDONARO, Lorenzo, 2003, "Marginalità transnazionali: modernità, migrazioni e nostalgia tra l'Arcipelago dei Bijagó (Guinea-Bissau) e Lisbona", Afriche e Orienti, 3-4: 206-222.

—, 2007, Living at the Margins: Youth and Modernity in the Bijagó Islands. Lisbon, ISCTE, PhD dissertation.

— - forthcoming, "'Culture stops development': Bijagó youth and the appropriation of the developmentalist discourse in Guinea-Bissau", African Studies Review. 
CARLING, Jørgen, 2001, Aspiration and Ability in International Migration: Cape Verdean Experiences of Mobility and Immobility. Oslo, Centre for Development and the Environment, University of Oslo, Dissertations \& Thesis, 5/2001.

—, 2002, "Migration in the age of involuntary immobility: theoretical reflections and Cape Verdean experiences”, Journal of Ethnic and Migration Studies, 28 (1): 5-42.

COllignon, René, and Mamadou DiOUf (eds.), 2001, Les Jeunes: Hantise de l'espace public dans les sociétés du sud?, special issue, Autrepart, 18.

FELDMAN-BIANCO, Bela, 2001, "Colonialism as a continuing project: the Portuguese experience", Identities, 8 (4): 477-482.

FERGUSON, James, 1999, Expectations of Modernity: Myths and Meanings of Urban Life on the Zambian Copperbelt. Berkeley, University of California Press.

GARDNER, Katy, 1993, "Desh-Bidesh: Sylheti images of home and away", Man, 28 (9): $1-15$.

—, 1995, Global Migrants, Local Lives: Travel and Transformation in Rural Bangladesh. Oxford, Clarendon Press.

HONWANA, Alcinda, and Filip DE BOECK (eds.), 2005, Makers and Breakers: Children and Youth in Postcolonial Africa. Oxford and Dakar, James Currey and Codesria.

INEP (ed.), 1990, Etude socio-économique des Îles Bijagós. Unpublished report.

KELSKY, Karen, 1999, "Gender, modernity, and eroticized internationalism in Japan”, Cultural Anthropology, 14 (2): 229-255.

LIECHTY, Mark, 1995, "Media, markets and modernization: youth identities and the experience of modernity in Kathmandu, Nepal”, in Vered Amit-Talai and Helena Wulff (eds.), Youth Cultures: A Cross-cultural Perspective. London and New York, Routledge, 166-201.

MBEMBE, Achille, 1985, Les Jeunes et l'Ordre Politique en Afrique Noire. Paris, L'Harmattan.

—, 2002, "African modes of self-writing", Public Culture, 14 (1): 239-273.

NEWITT, Malyn, 1981, Portugal in Africa: The Last Hundred Years. London, C. Hurst \& Co.

O'BRIEN, Donald B. Cruise, 1996, "A lost generation? Youth identity and state decay in West Africa”, in Richard Werbner and Terence Ranger (eds.), Postcolonial Identities in Africa. London and New Jersey, Zed, 55-74.

OLIVEIRA MARQUES, António H., 2001, "Aspectos da política geral”, in António H. Oliveira Marques (ed.), Nova História da Expansão Portuguesa (Volume XI). O Império Africano 1890-1930. Lisboa, Estampa, 21-30.

PINA CABRAL, João de, 2002, "Dona Berta's garden: reaching across the colonial boundaries”, Etnográfica, 6 (1): 77-91.

—, 2004, "Cisma e continuidade em Moçambique", in Clara Carvalho and João de Pina Cabral (eds.), A Persistência da História: Passado e Contemporaneidade em África. Lisboa, ICS, 375-393.

PRATT, Mary Louise, 1992, Imperial Eyes. London and New York, Routledge.

SILVA, António E. Duarte, 1997, A Independência da Guiné-Bissau e a Descolonização Portuguesa. Porto, Afrontamento.

SILVEIRA, Joel Frederico, 1998, "Guiné", in Valentim ALEXANDRE and Jill DIAS (eds.), Nova História da Expansão Portuguesa (Volume X). O Império Africano 1825-1890. Lisboa, Estampa, $211-267$.

THOMAS, Philip, 2002, "The river, the road, and the rural-urban divide: a postcolonial moral geography from southeast Madagascar”, American Ethnologist, 29 (2): 366-391. 
TRAJANO FILHO, Wilson, 2002, "Narratives of national identity in the Web", Etnográfica, 6 (1): 141-158.

— 2004 , "A constituição de um olhar fragilizado: notas sobre o colonialismo português em África”, in Clara CARVAlHO and João de PINA CABRAL (eds.), A Persistência da História. Passado e Contemporaneidade em África. Lisboa, ICS, 21-59.

UTAS, Mats, 2005, “Victimcy, girlfriending, soldiering: tactic agency in a young woman's social navigation of the Liberian war zone", Anthropological Quarterly, 78 (2): 403-430.

VAN BINSBERGEN, Wim, Rijk VAN DIJK, and Jan-Bart GEWALD, 2004, "Situating globality: African agency in the appropriation of global culture, an introduction", in Wim van Binsbergen and Rijk van Dijk (eds.), Situating Globality: African Agency in the Appropriation of Global Culture. Leiden, Brill, 3-54.

VIGH, Henrik, 2006, Navigating Terrains of War. Oxford, Berghahn.

Sai fora: jovens, desconexão e aspiração à mobilidade no arquipélago dos Bijagós (Guiné-Bissau) - Lorenzo Bordonaro - Centro em Rede de Investigação em Antropologia • lorenzo. bordonaro@iscte.pt

Neste artigo pretendo descrever a marginalidade, a exclusão e a imobilidade social dos jovens que vivem no pequeno porto de Bubaque, no arquipélago dos Bijagós. Relutantes a serem envolvidos na economia da aldeia, mas excluídos da economia do mercado do porto, conscientes da fragilidade da economia nacional, a migração para a Europa aparece-lhes como a única forma viável de promoção social. Contudo, o dinheiro e a educação não são as únicas motivações para a sua aspiração à mobilidade. As fantasias de migração para Europa dos jovens homens assentam numa narrativa desenvolvimentista que cria uma cartografia de centros e periferias. A mobilidade em direcção ao "norte" é portanto concebida também como uma oportunidade para conseguir - ou pelo menos para reivindicar - o direito de cidadania na "modernidade".

PALAVRAS-CHAVE: jovens, Guiné-Bissau, arquipélago dos Bijagós, imobilidade involuntária, migração, marginalidade. 